\title{
MIRIAM ROSSI
}

Uniwersytet w Tallinie

miriam@tlu.ee

\section{ODGRYWANIE EMIGRACJI: TŁUMACZE-POECI LENINGRADZKIEGO PODZIEMIA ${ }^{1}$}

\section{Abstract \\ Performance of Exile: Poet-Translators in the Leningrad Underground}

Literary translation during the Soviet period has been mostly analysed in terms of conforming to or resisting the dominant ideology. However, there were spaces where translation practices were to a certain extent free from this dichotomy, though excluded from the official literary field. The focus of the article is the particular condition of displacement or exile experienced by the underground poets who lived in Leningrad during the 1980s. The samizdat poet-translator plays the role of an exile, living on the fringes of the society and creating a network in the underground. The outcomes of this "performance of exile" are the translated texts, which show the handprints of the translator's conditions. The article responds to Anthony Pym's call for humanizing Translation History, and using the sociological tools developed in Translation Studies by Daniel Simeoni and Moira Inghilleri, it investigates the role of context, agent and text in the poetry translation practice of late samizdat.

Keywords: poetry translation; samizdat; Leningrad; translation sociology; exile

Słowa kluczowe: przekład poezji; samizdat; Leningrad; socjologia przekładu; emigracja

${ }^{1}$ Artykuł powstał przy wsparciu Estońskiej Rady Badań Naukowych (grant PRG1206: “Translation in History, Estonia 1850-2010: Texts, Agents, Institutions and Practices"). 
Anna Achmatowa uważała, że nic nie niszczy poety bardziej niż przekładanie cudzych wierszy (Chukovskaya 1990: 131). W Związku Radzieckim praktyka przekładowa oznaczała zazwyczaj zniewolenie, ucieczkę czy wyrażanie siebie poprzez słowa innych. Tak było w przypadku wielu autorów niezależnych, na przykład Borysa Pasternaka czy samej Achmatowej. Dlatego badacze często opisują przekład jako narzędzie ideologii albo formę oporu autorów-tłumaczy, którzy w przekładach dopuszczanych przez władzę do druku przemycali pierwiastki buntu (Kay France 1987; Loseff 1989; Witt 2011; Baer 2016). Przedmiotem moich badań jest natomiast działalność translatorska podejmowana, jak można sądzić, nie tylko niezależnie od presji ideologicznej sowieckich władz, lecz także od pilnej potrzeby oporu wobec tej ideologii.

Tematem tego artykułu jest przekład poezji funkcjonujący w samizdacie, tajnym systemie wymiany nieocenzurowanych tekstów, charakterystycznym dla leningradzkiego podziemia od końca lat 50. XX wieku aż do upadku Związku Radzieckiego. Rosyjski termin samizdat jest połączeniem słów sam (,sam”) oraz izdat (,wyd.”, jak w skrócie od „wydawnictwo”, izdatielstwo), stworzonym w latach 40. na podobieństwo ówczesnego urzędowego nazewnictwa przez poetę Nikołaja Głazkowa, który nazywał swoją twórczość samsebjaizdat, a więc „sam-się-wyd” (por. Catalano, Guagnelli 2011: 5)².

Przyjmuję tu socjokulturowe podejście do przekładu poezji, postulowane w szczególności przez Jacoba Blakesleya (2019: 7-8) na podstawie narzędzi oraz terminologii rozwiniętych w badaniach nad przekładem przez Daniela Simeoniego (1998), Moirę Inghilleri (2005, 2014), Michaelę Wolf i Aleksandrę Fukari (2007), czy Johna Miltona i Paula Bandię (2009), a pierwotnie zaczerpniętych z socjologii Pierre'a Bourdieu; szczególnie istotne są tu koncepcje ,agenta”, ,pola” i „kapitału”. Korzystając z tych ram teoretyczno-metodologicznych, w poniższych rozważaniach omówię: 1) kontekst samizdatu w latach 80 . XX wieku, 2) agentów pola przekładowego, ze szczególnym uwzględnieniem dwóch tłumaczy-poetów, 3 ) teksty, wiersze przełożone przez nich w ostatniej dekadzie istnienia ZSRR.

Choć samizdat funkcjonował jako system odrębny od oficjalnie wydawanej twórczości literackiej, rzetelne badania powinny stronić od podejścia

2 Początkowo Głazkow działał z myślą o ustanowieniu własnego kręgu odbiorców, głównie przyjaciół. Praktyka przepisywania wierszy na maszynie i ich rozpowszechniania miała wówczas prywatny, intymny charakter. Jednak z czasem termin Głazkowa zaczęto kojarzyć z ruchem oporu oraz buntem, aż wreszcie stał się określeniem nielegalnego obiegu tekstów na terenie Rosji, Polski oraz byłej Czechosłowacji w okresie komunizmu. 
binarnego, zgłębiając relacje między obiegiem nieoficjalnym a oficjalnym oraz ich wzajemne oddziaływanie. Tego rodzaju współzależność była szczególnie istotna w latach 80 . XX wieku, kiedy to w samizdacie można było zaobserwować pewną dychotomię. $Z$ jednej strony można było dostrzec dążenie do niezależności, które przejawiało się tworzeniem nowych projektów wydawniczych, jak również ustanowieniem w 1978 roku nagrody imienia Andrieja Biełego (1880-1934) dla twórców działających w podziemiu. Z drugiej strony pojawiła się potrzeba uznania oraz udziału w kulturze oficjalnej - w 1981 roku powstał Klub-81, półoficjalna grupa literacka. Ta rozbieżność świadczy o tym, że agenci pola przekładowego działający w samizdacie doświadczali „,bycia pomiędzy”. Cechą charakterystyczną samizdatu lat osiemdziesiątych było rozdarcie między niezależnością a partycypacją, wynikające z zacierania się granic między sferą oficjalną a nieoficjalną.

W tym czasie część związanych z samizdatem agentów pola przekładowego pokonywała zarówno to rozdarcie, jak i granice ZSRR. Choć tłumaczenia, zwłaszcza tekstów poruszających kwestie polityczne, filozoficzne czy społeczne, krążyły w samizdacie od samego początku, dopiero w latach 80 . nastąpił rozkwit przekładu poezji. Powstało nawet czasopismo poświęcone przekładowi literackiemu - „Priedłog” (1984-1989). Tłumacze zaczęli odgrywać kluczową rolę w wydawnictwach podziemnych i stali się znacznie bardziej widoczni w środowisku leningradzkiego samizdatu. Większość z nich była równocześnie poetami, a nawet redaktorami czy wydawcami, jak w przypadku pisma „Priedłog”. W latach 80. ukazywały się również inne czasopisma publikujące przekłady poezji, na przykład „Czasy”(1976-1990), „Obwodnyj kanał” (1981-1993) czy „Siewiernaja poczta” (1979-1981). Nadejście pieriestrojki nie przerwało ich druku, co świadczy o tym, że samizdat nie przestał być potrzebny aż do końca dekady.

Współistnienie zależności i niezależności, obiegu oficjalnego i nieoficjalnego, a także różnorodność ról tłumaczy-poetów związanych z samizdatem wiążą się ze zjawiskiem przemieszczenia - teksty publikowane w samizdacie ulegały przemieszczeniu, ponieważ musiały funkcjonować poza oficjalnym polem literackim (Baer 2016: 116; Burt 1998: 17)³.

Te wstępne rozważania prowadzą do następującego pytania badawczego: dlaczego poeci zmuszeni do przyjmowania roli tłumaczy w kontekstach oficjalnych, którzy jednak mogli wydawać swoją twórczość w samizdacie,

${ }^{3}$ Opierając się na rozważaniach Roberta Burta, Brian J. Baer (2016) przeciwstawiał przemieszczenie (displacement) zjawisku zastępowania (replacement). 
nadal przekładali poezję zagraniczną na potrzeby drugiego obiegu, publikując tłumaczone wiersze obok własnych?

Poszukując odpowiedzi, przyjrzę się trzem powiązanym płaszczyznom kontekstu, agenta pola przekładowego oraz tekstu. Najpierw zbadam relację między kontekstem a agentami w odniesieniu do działalności tłumaczy-poetów samizdatu. Następnie zilustruję te praktyki, opisując dwa przypadki tłumaczy-poetów zarówno pod kątem doboru tłumaczonych tekstów, jak i charakterystyki samych przekładów. W ten sposób zamierzam zbadać genezę konkretnych przekładów, biorąc pod uwagę kontekst społeczno-kulturowy, w którym funkcjonowali ich autorzy.

\section{Kontekst a agent pola przekładowego}

Zdaniem Alexeia Yurchaka okres ,późnego socjalizmu” rozpoczął się w połowie lat 50. XX wieku i zakończył w połowie lat 80 . z nadejściem pierestrojki (2005: 4). Proponuję jednak, by posługiwać się tym określeniem również w odniesieniu do drugiej połowy lat 80., aż do upadku ZSRR w 1991 roku. Choć polityka pierestrojki niewątpliwie wywarła wpływ na drugą połowę lat 80. (Zalambani 2007:171), aż do rozpadu ZSRR nie przełożyła się na ujednolicone praktyki. Pomimo rozkwitu oficjalnego rynku wydawniczego w drugiej połowie dekady (Yurchak 2005: 128), pod koniec istnienia ZSRR przestarzałe instytucje cenzury nadal funkcjonowały, chcąc ocalić swoją pozycję (Zalambani 2009: 217). Co więcej, rehabilitacja znacznej części rosyjskich, a także zagranicznych autorów nastąpiła dopiero w 1989 roku wraz z otwarciem specchranów w bibliotekach i archiwach - zbiorów specjalnych o ograniczonym dostępie, w których trzymano książki (zarówno autorów rosyjskich, jak i zagranicznych) uważane za niezgodne z obowiązującą sowiecką ideologią. W 1990 roku wolność prasy została ogłoszona w Ustawie o prasie i środkach masowego przekazu, a w 1991 roku zlikwidowano Gławlit - główny organ radzieckiej cenzury. Od tego momentu innowacje zainicjowane w okresie pierestrojki były stopniowo wprowadzane w życie, kładąc kres epoce sowieckiej.

Pokolenie, o którym tutaj mowa, definiowane jest zatem przez Yurchaka jako „ostatnie sowieckie pokolenie” (2005), które znacznie różniło się od poprzedników w podejściu do niezgody i oporu: szestidiesiatniki (,,sześćdziesiątnicy", urodzeni w latach 60.) sprzeciwiali się władzy w sposób bardziej czynny i jawny. Ostatnie sowieckie pokolenie natomiast wyrażało 
sprzeciw, czy też po prostu okazywało brak zainteresowania, głównie poprzez samowykluczenie i alienację. Większość późnoradzieckich autorów związanych z podziemiem pracowała w kotłowniach, stróżówkach czy też wykonywała inne prace o niskim prestiżu społecznym. Jak wyjaśnia Marco Sabbatini, taki wybór pozwalał im żyć na obrzeżach społeczeństwa, którym gardzili (2008: 341).

Tego rodzaju praca dawała im również sporo czasu wolnego, który mogli poświęcić pisaniu, uciekając od sowieckiej rzeczywistości. W latach 70. było tak w przypadku Siergieja Stratanowskiego, Wiktora Kriwulina czy Jeleny Szwarc, poetów podziemia, których wiersze łączyło poszukiwanie tego, co boskie, w leningradzkiej codzienności. Wyrażana w ich poezji duchowość nie była szczególnie ortodoksyjna czy tradycyjna, zachowały się w niej jednak pewne ślady teologii chrześcijańskiej (Sabbatini 2008; Von Zitzewitz 2015): wizja ludzkiego życia i Boga jest w ich wierszach zniekształcona, niemalże groteskowa. Ze względu na mistyczny rys ta poezja jest daleka od politycznego zaangażowania.

Zainteresowanie teologią i filozofią wyrażało się nie tylko w poezji. W leningradzkim podziemiu często odbywały się poświęcone im seminaria oraz spotkania. Stratanowski, który publikował swoje wiersze oraz przekłady z francuskiego w czasopismach literackich samizdatu oraz był współzałożycielem jednego z nich („Obwodnyj kanał”, 1981-1986)4, wspomina: „była (...) grupa religijno-filozoficzna, która spotykała się u mnie domu (stali członkowie: Kiryłł Butyrin, Aleksandr Żydkow, Nikołaj Il’in i ja)" (Lygo 2010: 115). Najbardziej znanym seminarium teologiczno-filozoficznym było niewątpliwie to prowadzone przez Tatianę Goriczewą i Kriwulina w latach 1974-1980. W spotkaniach tych uczestniczyło wielu młodych dysydentów, wśród nich wspomniany Żydkow i Grigorij Bieniewicz. Żydkow i Bieniewicz byli również zaangażowani w działalność wydawnictw podziemnych jako poeci i tłumacze. Ich wiersze i przekłady ukazywały się w takich samizdatowych czasopismach, jak „Czasy”, „Obwodnyj Kanał” czy „Predlog”.

Obok Żydkowa i Bieniewicza w leningradzkim samizdacie brało udział wielu innych tłumaczy-poetów. Najpłodniejszymi twórcami w tym gronie byli Arkadij Dragomoszczenko, Michaił Jossel, Siergiej Chrienow, Władimir Kuczeriawkin, Michaił Chazin oraz Siergiej Magid. Uznanie przyniosła im w szczególności własna poezja oraz działalność edytorska - byli

${ }^{4}$ W Sankt Petersburgu rzeczywiście jest Kanał Obwodowy, który ówcześnie znajdował się na obrzeżach miasta. 
założycielami i głównymi redaktorami czasopisma „Priedłog” (Lazzarin 2011: 215). Publikując własną poezję oraz przekłady, kontynuowali wieloletnią tradycję rosyjskich tłumaczy-poetów (Khotimsky 2018: 220).

Przekład poezji zajmuje w historii literatury rosyjskiej poczesne miejsce. Władimir Sołowjow twierdził wręcz, że przekład utworu Thomasa Graya Elegy Written in a Country Churchyard autorstwa Korneja Żukowskiego (Elegija, napisannaja na sielskom kładbiszcze) „można uznać za początek prawdziwie ludzkiej poezji w Rosji po oratorskim triumfie epoki Dierżawina" (Baer 2016: 2-3). Wielu wybitnych poetów rosyjskich zajmowało się przekładem, zwykle z myślą o wzbogaceniu własnej poetyki i ożywieniu procesu twórczego (Lazzarin 2011: 209; Baer 2016).

Jednak w samizdacie praktyka przekładu poezji naznaczona była przemieszczeniem - tłumacze-poeci pełnili funkcję agentów w przestrzeni podziemia, a nie pola literackiego. Przemieszczenie tłumaczy-poetów i ich tekstów można porównać do emigracji, której na przestrzeni dziejów doświadczyło wielu rosyjskich intelektualistów, w szczególności XIX- oraz XX-wiecznych poetów, którzy musieli opuścić kraj głównie z przyczyn politycznych. Ucieczka - z ojczyzny lub od języka ojczystego, fizyczna, duchowa czy wyobrażona - ściśle wiąże się z przekładem: łacińskie translatio oznacza wszak zarówno przemieszczanie się z miejsca na miejsce, jak i przekład z jednego języka na drugi. Doświadczenie emigracji ma zatem związek z dualizmem języka i przestrzeni, który, jak stwierdza Svetlana Boym, pociąga za sobą dwoistość [double-ness] świadomości, czasu i przestrzeni (2001: 254).

Żyjący na obczyźnie pisarze mieli zazwyczaj silne poczucie solidarności ze współemigrantami (Said 2000: 141), a swoją twórczość postrzegali jako faktyczną kontynuację literatury kraju ojczystego. To poczucie solidarności i ciągłości towarzyszyło także tłumaczom-poetom samizdatu (Parisi 2013: 85-87), co jeszcze mocniej łączyło ich z wcześniejszymi pokoleniami rosyjskich pisarzy, którzy doświadczyli emigracji i którzy mieli stać się klasykami literatury rosyjskiej (Bethea, Frank, 2011: 195). Tłumacze-poeci samizdatu i emigranci mieli jeszcze dwie cechy wspólne: nie cieszyli się uznaniem w ojczyźnie i pracowali z językami obcymi. Różnili się jednak znacząco w swoim podejściu do obu tych kwestii. Twórcy leningradzkiego samizdatu wykształcili postawę dystansu czy wręcz obojętności wobec społeczeństwa, w którym żyli. W przeciwieństwie do nich, wielu rosyjskich intelektualistów, którzy wyemigrowali w okresie sowieckim, żywo przejmowało się losami kraju i angażowało w działalność opozycyjną. 
W środowisku samizdatu języki obce odbierano pozytywnie, ponieważ nie postrzegano ich jako przeszkody dla tworzenia rosyjskojęzycznej poezji, w kręgu emigracyjnym zaś - przeciwnie. W samizdacie obcojęzyczne źródła inspiracji literackich oraz działalność translatorską traktowano jako szansę na nawiązanie dialogu z poetami funkcjonującymi w innych kontekstach oraz na owocne spotkanie $\mathrm{z}$ innymi realiami.

Tłumacze z kręgu samizdatu byli w większości samoukami, którzy działalność translatorską postrzegali jako sposób włączenia zagranicznych poetów do swojego podziemnego kręgu literackiego. Poczucie, że podziemie i zdegradowana rzeczywistość późnosocjalistycznego Leningradu zyskiwały międzynarodowy wymiar dzięki ich szerokiemu oczytaniu oraz twórczości przekładowej, jest doskonale widoczne w wierszu Obraz Bieniewicza (2015).

Kuchnia - wot nasza Sorbonna,

I kotiel'naja - nasz Oksfor;

W Giejdiel'biergie koridorow

Kommunalnych, na kartoszkie

Garwarda owoszczebazie, -

Wot gdie my obrazowanie

Połuczili.

............ Eto razwie

Możno zagłuszyt' soznanijem? ${ }^{5}$

Działalność leningradzkich tłumaczy-poetów miała więc służyć dwóm celom: przede wszystkim stworzeniu nowego środowiska literackiego, w którym byłoby miejsce dla zagranicznych autorów, a także metaforycznemu doświadczaniu życia na obczyźnie dzięki zanurzeniu się w innym świecie poprzez poezję. Twórcy samizdatu odczuwali to, co opisuje Boym: ,język obcy jest, podobnie jak sztuka, rzeczywistością alternatywną, światem potencjalnym. Gdy go odkryjesz, nie będzie już powrotu do jednojęzycznej egzystencji” (Boym 2001: 165).

Przekład poezji jest zatem pomostem łączącym teraźniejszość z przeszłością, Leningrad lat 80. z dawnym Piotrogrodem, z którego emigrowali

5 „Kuchnia - nasza Sorbona / I kotłownia - nasz Oksford / W Heidelbergu korytarzy / komunalnych, na Harvardzkim bazarku z warzywami, / oto gdzie zdobyliśmy / wykształcenie. /...... Czy to / można przemilczeć z czystym sumieniem?" 
rosyjscy poeci, nastroje antyradzieckie z antycarskimi, zakorzenionym w dłuższej i bardziej złożonej tradycji kulturowej. Kontekst samizdatu sprawił, że agenci pola literackiego zmagali się z przemieszczeniem poprzez praktykę przekładową. Tłumaczenie poezji obcojęzycznych twórców nie było dla nich ograniczeniem, jak w przypadku innych autorów, lecz wyborem, dzięki któremu mogli nawiązać kontakt z innymi językami, literaturami, światami. W pewnym sensie funkcjonowali więc tak, jak gdyby byli na emigracji - i dzięki tej metaforycznej emigracji w samizdat mogli tworzyć i rozpowszechniać zarówno własne wiersze, jak i przekłady.

\section{Agent pola przekładowego a tekst}

Zdaniem Anthony'ego Pyma, przekładoznawstwo musi potrafić ,zobiektywizować to, co subiektywne" (Pym 2009: 25), a więc uwidocznić i obiektywnie opisać to, co dzieje się na poziomie thumacza-podmiotu. Oznacza to, że ślady agenta pola przekładowego można dostrzec zarówno w doborze tekstów, jak i w samych przekładach. Zgodnie z postulowaną przez Pyma humanizacją badań nad przekładem, w praktyce przekładowej można odnaleźć tropy relacji między agentami a kontekstami. W poniższej analizie przyjrzę się śladom pozornej, „odgrywanej” emigracji w twórczości dwóch tłumaczy-poetów: Żydkowa i Bieniewicza.

Aleksander Żydkow (ur. 1947) ukończył anglistykę na wydziale filologicznym Leningradzkiego Uniwersytetu Państwowego i pracował jako nauczyciel języka angielskiego. Grigorij Bieniewicz (ur. 1956), z wykształcenia inżynier, z powołania tłumacz-poeta, został ze względu na swoje poglądy polityczne usunięty z Komsomołu, sowieckiej organizacji młodzieżowej. Zamiast jako inżynier, musiał pracować jako nauczyciel fizyki, a później jako operator kotła gazowego (1983-1993), jednocześnie aktywnie angażując się w redagowanie i publikowanie samizdatowych czasopism.

Ze względu na konspiracyjny charakter samizdatu oraz związane z tą działalnością ryzyko, nie zachowały się wszystkie numery periodyków. Udało się jednak zebrać spisy treści większości z nich, a tym samym odtworzyć zawartość publikacji, choć nie zawsze w pełni dokładnie - zdarza się, że spis treści nie wymienia tytułów poszczególnych wierszy, jak w przypadku dwóch numerów czasopisma „Priedłog” uwzględnionych w tabeli 1 - numeru 3 z sześcioma wierszami Yeatsa oraz numeru 7 poświęconego XX-wiecznej literaturze amerykańskiej. 
Tabela 1. Przekłady poetyckie Grigorija Bieniewicza opublikowane w samizdacie

\begin{tabular}{|c|c|c|c|c|}
\hline \multicolumn{5}{|c|}{ Grigorij Bieniewicz } \\
\hline $\begin{array}{l}\text { Tytul i numer } \\
\text { czasopisma }\end{array}$ & $\begin{array}{l}\text { Rok } \\
\text { wydania }\end{array}$ & $\begin{array}{l}\text { Autor } \\
\text { oryginału }\end{array}$ & Tłumaczone teksty & Dostępność \\
\hline „Priedłog” nr 3 & 1984 & W.B. Yeats & $\begin{array}{l}\text { - } 6 \text { wierszy } \\
\text { - An Irish Airman Fore- } \\
\text { sees his Death } \\
\text { - The Phases of the } \\
\text { Moon }\end{array}$ & $\begin{array}{l}\text { Nie } \\
\text { Tak } \\
\text { Nie }\end{array}$ \\
\hline „Priedłog” nr 7 & 1985-1986 & \multicolumn{2}{|c|}{ Literatura amerykańska XX wieku } & Nie \\
\hline „Czasy” nr 59 & 1986 & W.B. Yeats & $\begin{array}{l}\text { - The Phases of the } \\
\text { Moon } \\
\text { - An Irish Airman fore- } \\
\text { sees his Death } \\
\text { - All Souls'Night } \\
\text { - The Second Coming } \\
\text { - Ribh at the Tomb of } \\
\text { Baile and Aillinn }\end{array}$ & Tak \\
\hline \multirow[t]{2}{*}{ „Priedłog” nr 13} & \multirow[t]{2}{*}{1987} & W.H. Auden & August 1968 & \multirow[t]{2}{*}{ Tak } \\
\hline & & Roald Hoffmann & Svoloch & \\
\hline
\end{tabular}

Źródło: opracowanie własne.

Tabela 2. Przekłady poetyckie Aleksandra Żydkowa opublikowane w samizdacie

\begin{tabular}{|l|l|l|l|l|}
\hline \multicolumn{5}{|c|}{ Aleksandr Żydkow } \\
\hline $\begin{array}{l}\text { Tytul i numer } \\
\text { czasopisma }\end{array}$ & $\begin{array}{l}\text { Rok } \\
\text { wydania }\end{array}$ & $\begin{array}{l}\text { Autor } \\
\text { oryginału }\end{array}$ & Tlumaczone teksty & Dostępność \\
\hline „Czasy” nr 39 & 1982 & W.B. Yeats & $\begin{array}{l}\text { - Sailing to Byzantium } \\
- \text { Leda and the Swan }\end{array}$ & Tak \\
\hline „Obwodnyj kanał” nr 1 & 1981 & John Donne & - The Apparition & Tak \\
\hline „Obwodnyj kanał” nr 5 & 1984 & John Donne & $\begin{array}{l}\text { - Witchcraft by a Picture } 6 \\
- \text { The Apparition }\end{array}$ & Tak \\
\hline
\end{tabular}

Źródło: opracowanie własne.

Jak wynika z zestawień w tabelach 1 i 2, mimo dzielących ich różnic, Żydkowa i Bieniewicza łączyła pasja do poezji W.B. Yeatsa. W dalszej części artykułu zastanowię się nad przyczynami ich wyborów, biorąc pod uwagę

6 Tytuł przetłumaczony jako Czornaja magia. 
zarówno kontekst samizdatu lat 80., jak i związek tych decyzji z literaturą i kulturą przedrewolucyjnej Rosji. Skupię się na kryteriach wyboru tłumaczonych tekstów a następnie przeanalizuję przekład Żydkowa, który dobrze ilustruje sygnaturę tłumacza.

Grigorij Bieniewicz, jak sam stwierdził (korespondencja prywatna, 2016), postanowił tłumaczyć Yeatsa $\mathrm{z}$ dwóch powodów: ze względu na unikalność jego poezji na tle rosyjskiej tradycji literackiej oraz na brak jej przekładów na język rosyjski. W twórczości Yeatsa fascynowały go w szczególności wątki mistyczne, co mogło wynikać z jego zainteresowania filozofią i teologią. Dlatego zdecydował się na przekład jednego z najbardziej mistycznych i filozoficznych wierszy poety - The Phases of the Moon, w którym Yeats przedstawił swój system przekonań: każda faza księżyca odpowiada konkretnej postaci, zazwyczaj literackiej, która reprezentuje pewien typ zachowania czy cechę charakteru. Yeats łączy w tym wierszu to, co metafizyczne, z tym, co fizyczne, literackie z ludzkim, społeczne z osobistym.

Bieniewicz przełożył kilka wierszy Yeatsa, ale tylko jeden Audena - $A u$ gust 1968. Temat wiersza jest ściśle związany ze światem sowieckim, jako że Auden napisał go w reakcji na radziecką okupację Czechosłowacji. Związek Radziecki przedstawiony jest tu jako potwór-ludożerca, który walczy i wygrywa, lecz nie posiada daru słowa i jedynie ,bełkot leje mu się z warg” (Auden 1991). Przekładając ten wiersz o inwazji oraz przeciwko niej, Bieniewicz nagłaśniał postawę Audena, sytuując go tym samym po stronie dysydentów.

Należy też pamiętać o związkach łączących Yeatsa, Audena i Josifa Brodskiego. W 1939 roku Auden napisał wiersz In Memory of W.B. Yeats (Pamięci W.B. Yeatsa, przeł. S. Barańczak), który Brodski niemal dwie dekady później odkrył przypadkiem w pożyczonym od znajomego tomiku angielskiej poezji. Elegia tak bardzo go poruszyła, że gdy w styczniu 1965 roku zmarł T.S. Eliot, Brodski, wzorując się na niej, napisał Na smiert'T.S. Eliota (Pamięci T.S.Eliota, przeł. W. Woroszylski). Później, gdy Brodski wyemigrował, zaprzyjaźnił się z Audenem, który nie tylko pomagał mu w sprawach praktycznych, lecz także był dla niego ważnym źródłem inspiracji i wiedzy (Bethea 2009: 363-380). Brodski wyraził swój podziw dla Audena w eseju To Please a Shadow (1986), a kiedy zmarł przedwcześnie (28 stycznia, jak W.B. Yeats), Seamus Heaney napisał elegię, w której pojawia się wątek więzi między Brodskim, Audenem a Yeatsem.

Być może więc wybierając Yeatsa i Audena, Bieniewicz wpisywał swoją praktykę przekładową w tradycję sygnowaną nazwiskiem Brodskiego, który sam będąc tłumaczem-poetą, stanowił ważny punkt odniesienia w kręgach 
samizdatu. Po procesie o pasożytnictwo stał się symbolem niezależnej inteligencji (Pavan 2009: 24) ${ }^{7}$, a emigracja i kariera poetycka w USA uczyniły go postacią jeszcze ważniejszą dla tego środowiska.

Trzecim tłumaczonym przez Bieniewicza poetą był Roald Hoffmann (ur. 1937), polski chemik, który wyemigrował do USA. Pod koniec lat 80. Hoffmann zaczął pisać poezję w języku angielskim. Jej głównym (choć nie jedynym) tematem były jego badania naukowe. Wiersz Svoloch (Swołocz) ukazał się po raz pierwszy w 1987 roku i jeszcze tego samego roku został opublikowany w przekładzie Bieniewicza w 13 numerze czasopisma „Priedłog”.

W przypadku wyboru tego wiersza prawdopodobnie decydujący był temat. Hoffmann opisuje celnika z lotniska Moskwa-Szeremietiewo, który skonfiskował mu poezję Cwietajewej i Brodskiego: "But for you, the expert in a gray suit, / authority, it was left to take Tsvetaeva, two slim volumes of Joseph Brodsky" (1987: 98) ${ }^{8}$. Przekładając ten wiersz, Beniewicz składa hołd rosyjskiej poezji zakazanej w ZSRR (reprezentująca Rosję przedrewolucyjną Cwietajewa), ponownie pojawia się tu również postać Brodskiego.

Bieniewicz wybierał poetów i ich utwory według własnych zainteresowań literackich, a także ze względu na ich kapitał symboliczny. Tłumaczeni przez niego poeci byli związani z Brodskim lub otwarcie nawiązywali do problemów świata sowieckiego, o czym świadczy jego decyzja o przekładzie August 1968 Audena czy Svoloch Hoffmanna.

Żydkow, podobnie jak Bieniewicz, tłumaczył Yeatsa, ale także Johna Donne'a. Ten wybór prawdopodobnie wiąże się z jego wykształceniem w zakresie literatury angielskiej, choć może też być związany z twórczością Brodskiego. Brodski zaczął czytać poezję Donne'a na zesłaniu w obozie pracy pod Archangielskiem (tom był prezentem od Lidii Czukowskiej). Wiedział już o Donnie z motta To Whom the Bell Tolls (Komu bije dzwon, przeł. Bronisław Zieliński) Hemingwaya, teraz mógł jednak zgłębić jego

7 Procesy Brodskiego z 1964 roku oraz tłumaczy Siniawskiego i Daniela z 1965 roku potwierdziły, że system radzieckich represji nie zmienił się mimo chruszczowowskiej odwilży. Oskarżenie Brodskiego o pasożytnictwo oraz prześladowania dwóch intelektualistów za ich literacką aktywność postrzegane były jako powrót do stalinizmu. Krążące w obiegu samizdatowym stenogramy z tych procesów uwidaczniały fikcyjny charakter procedur prawnych podejmowanych przez władze. W szczególności proces Brodskiego stanowił symboliczny porog (próg) życia kulturalnego Leningradu. W liście do poety Anna Achmatowa nazwała proces Brodskiego „Sądem Ostatecznym”.

8 „Ale tobie, ekspercie w szarym garniturze / władzo, pozostało zabrać Cwietajewą, dwa cienkie tomiki Josifa Brodskiego". 
styl i tematykę, a także przełożyć kilka wierszy. Lektura i praca nad przekładem wywarły na Brodskiego tak duży wpływ, że zaczął nawet nazywać siebie uczniem Donne'a w kwestii budowania strof, a później napisał wiersz Bol'szaja elegija Dżonu Donnu, który od połowy lat 60. krążył w samizdacie (Pomerantsev 2010 $)$. W nieoficjalnym polu literackim skojarzenie z Brodskim nadawało poezji Donne'a szczególnie duży kapitał symboliczny, co prawdopodobnie przyczyniło się do decyzji Żydkowa, by sięgnąć po jego teksty z myślą o samizdatowch przekładach.

Przejdę teraz do omówienia przekładu słynnego Sailing to Byzantium Yeatsa (Żeglując do Bizancjum, przeł. Ludmiła Marjańska) autorstwa Żydkowa. Ilustracje 1 i 2 przedstawiają fragmenty opublikowanego w samizdacie tekstu, w charakterystycznej dla tych czasopism „maszynopisowej” formie.

Już sam tytuł wersji Żydkowa niejako odzwierciedla poczucie przypominającego emigrację wyobcowania towarzyszące członkom leningradzkiego podziemia: Irłandiec $w$ Wizantii (Irlandczyk w Bizancjum). W ten sposób tłumacz podkreśla tożsamość narodową Yeatsa i jego status cudzoziemca w miejscu, do którego nie przynależy. Żydkow przekłada wiersz ze stosunkowo dużą swobodą interpretacyjną, nie zaburzając jednak regularnej budowy oryginału. Zachowuje oryginalny układ rymów, co prawdopodobnie wymusiło liczne przesunięcia w obrazowaniu i warstwie znaczeniowej.

Żydkow dodaje pewne elementy nieobecne w oryginale, na przykład tłumacząc pierwszy wers - "That is no country for old men” („To nie jest kraj dla starych ludzi”) jako „Starost' w czużych dieriewach małoletja...” (,Starość w cudzych/obcych drzewach krótkotrwała...”).

Tłumacz tworzy autorski, sugestywny obraz życia spędzonego pośród drzew, które należą do kogoś innego; wers ten nie ma odpowiednika w żadnym elemencie oryginału. Jego dodanie podkreśla motyw emigracji i trudności życia na obczyźnie. Przykład ten pokazuje, że w niektórych przypadkach strategia przekładowa tumaczy-poetów samizdatu polegała przede wszystkim na odważnej interpretacji oryginalnego tekstu.

Podczas gdy w oryginale to Bizancjum jest jedynym wspomnianym miastem, w przekładzie Żydkowa pojawia się również Rawenna. Wers „O sages standing in God's holy fire / As in the gold mosaic of a wall" (Yeats 1994: 163, por. „O mędrcy, których święty ogień Boga sięgnął, / Jak na złoconych mozaikach na murze”) brzmi w rosyjskim przekładzie „Rawienskaja

\footnotetext{
9 Wywiad z Igorem Pomierancewem przeprowadzono w 1981 roku.
} 
mozaika-tieplica/ swiatych mistierij, swietłyj wodojom” („Raweńska mozaika-szklarnia/ świętych misteriów, świetlisty staw").

\section{Старость в чугех дөревах халолетья...}

Il. 1. Pierwszy wers Sailing to Byzantium Yeatsa w przekładzie Aleksandra Żydkowa. Źródło: Internetowe archiwum samizdatu Centrum Andrieja Biełego, http://samizdat. wiki/images/2/2a/ЧАСЫ39-12-Жидков.pdf (dostęp 30.12.2020)

\section{Равеннокая мовауга-төплица .. Святых мистерй, светлыи вотоек,-}

Il. 2 Fragment Sailing to Byzantium Yeatsa w przekładzie Aleksandra Żydkowa Źródło: Internetowe archiwum samizdatu Centrum Andrieja Biełego, http://samizdat. wiki/images/2/2a/ЧАСЫ39-12-Жидков.pdf (dostęp 30.12.2020)

To dodatkowe odniesienie geograficzne ma swoją symbolikę. W literaturze rosyjskiej Rawennę można wręcz traktować jako topos - wielu rosyjskich poetów zachwycało się tym miastem i opisywało je w swoich utworach, w szczególności symboliści, między innymi Aleksandr Błok, który poświęcił mu jeden z wierszy (Blok 1981: 93; por. Kopper 1994: 39; Presto 2008: 75, 83-87). Przywołanie Rawenny podkreśla więc ciągłość tradycji kulturowej, a także odsyła do jednego z najznamienitszych wygnańców - Dantego Alighieri. Motyw Dantego jako emigranta często pojawia się w rosyjskiej poezji - Błok kończy swój wiersz Rawenna obrazem cienia Dantego, Achmatowa wspomina stosunek Dantego do Florencji, którą kochał i której równocześnie nienawidził (1992: 395), w wierszu Niewozwraszczeniec (Dezerter) Iwan Elagin (1918-1987) bezpośrednio zwraca się do Dantego jako „biednego emigranta” (1998: 325) na obczyźnie, czyli w Rawennie.

Decyzja Żydkowa, by zamienić Bizancjum na Rawennę, nawiązuje do toposu miasta i uwydatnia ledwie zarysowany w oryginale motyw emigracji. Odczytując wiersz Yeatsa przez pryzmat przemieszczenia, Żydkow wykracza poza tekst wyjściowy źródłowy i daje odbiorcy docelowemu konkretny klucz interpretacyjny, dostosowany do rzeczywistości leningradzkiego podziemia. 


\section{Wnioski}

Działalność translatorska w leningradzkim samizdacie późnego socjalizmu była formą odzyskania (re-appropriation) praktyki przekładowej przez rosyjskich poetów. Działania, które w kontekstach oficjalnych postrzegane były jako nakaz lub substytut, w podziemiu stawały się wolnym twórczym wyborem. W tym sensie samizdat kończy zaobserwowany przez Monticellego proces deautoryzacji (de-authorization; 2016: 420), ponieważ obok przekładów autorom wolno już publikować własne wiersze. Podczas gdy Pasternak thumaczył, by zrealizować narzucony odgórnie „projekt kulturowy" (Witt 2013: 154) - co nie zmienia faktu, że jego przekłady są jednymi z największych osiągnięć literackich epoki sowieckiej - przekłady publikowane w leningradzkim samizdacie były rezultatem niezależnych wyborów tłumaczy. Kontekst samizdatu jawi się jako „nie-miejsce”, jako ziemia poetów wygnanych, którzy ignorują rzeczywistość radziecką, by powrócić do źródeł rosyjskiej tradycji. Działalność tłumaczy-poetów samizdatu zrodziła się z chęci poznawania światów literackich istniejących poza blokiem sowieckim i wyraźnie podkreślała „emigrancką” kondycję leningradzkich twórców. Na wybory przekładowe, w szczególności proces selekcji materiału, znaczący wpływ miała postać Brodskiego - wybitnego poety-wygnańca. Przypisywany mu kapitał symboliczny widoczny jest w decyzjach thumaczy-poetów samizdatu, którzy wybierali teksty podziwianych przez Brodskiego, a czasem już przez niego tłumaczonych autorów.

Samizdat był przestrzenią „odgrywania” kondycji emigracyjnej: kulturowe praktyki publikowania czasopism i przekładania obcojęzycznej poezji odzwierciedlają model działalności kulturalnej „starej emigracji’, a także wskazują na solidarność członków samizdatu oraz jednoczące ich poczucie osamotnienia. Co ciekawe, te praktyki kulturowe tłumaczy-poetów samizdatu nie odpowiadają schematowi podwójnego życia, charakterystycznemu zdaniem niektórych autorów dla ostatniego sowieckiego pokolenia. Zamiast oficjalnie wieść życie pełne pozorów, a prywatnie - życie „autentyczne”, thumacze-poeci samizdatu wycofali się do strefy prywatnej i to w niej odgrywali emigrację. W kręgu przyjaciół mogli kreować nowe światy, a działając na wzór rosyjskich emigrantów, realizowali interpretacyjną misję przekładu. 


\section{Bibliografia}

Akhmatova A. 1992. The Complete Poems of Anna Akhmatova, Edinburgh: Zephir. Auden W.H. 1979. Selected Poems, New York: Vintage Books.

—. 1991. Sierpień 1968, przeł. S. Barańczak, „Tygodnik Literacki” 6, s. 11.

Baer B. J. 2016. Translation and the Making of the Modern Russian Literature, New York: Bloomsbury.

Bethea, D. 2009. The Superstitious Muse: Thinking Russian Literature Mythopoetically, Boston: Academic Studies Press.

Bethea, D., S. Frank. 2011. Exile and Russian Literature, w: E. Dobrenko, M. Balina (red.), The Cambridge Companion to Twentieth-Century Russian Literature, Cambridge University Press, Cambridge-New York-Melbourne, s. 195-214.

Bieniewicz G. 2015. Niekotoryje wos 'mistiszija, „Żurnał poezji «Pławuczij most»” 2(6), http://www.plavmost.org/?p=5276 (dostęp: 23.11.2020).

Blakesley J. (red.). 2019. Sociologies of Poetry Translation, London: Bloomsbury.

Blok A. 1981. The Twelve and Other Poems, Oxford: Oxford University Press.

Boym S. 2001. The Future of Nostalgia, New York: Basic Books.

Brodsky I. 1986. Less Than One: Selected Essays, New York: Farrar, Straus \& Giroux. Burt R. 1998. Unspeakable ShaXXXspeares, New York: Palgrave Macmillan.

Catalano A., Guagnelli S. 2011. La luce dell'est: il samizdat come costruzione di una comunità parallela, ,eSamizdat” 8, s. 5-17.

Chukovskaya L. 1990. Incontri con Anna Achmatova, przeł. G. Moracci, Milano: Adelphi.

Dolinin W. 2011. Niepodcenzurnyje żurnaty Leningrada sieriediny 1950-1980-ch godow, „eSamizdat” 8, s. 189-200.

Ełagin I. 1998. Sobranije soczinienij w dwuch tomach, t.1. Moskwa: Sogłasije.

Fukari A., Wolf M. (red.). 2007. Constructing a Sociology of Translation, Amsterdam: John Benjamin Publishing Company.

Hoffman R. 1987. Svoloch, „New York Quarterly” 33, s. 98.

Inghilleri M. 2005. The Sociology of Bourdieu and the Construction of the 'Object' in Translation and Interpreting Studies, „The Translator” 11(2), s. 125-145.

Inghilleri M. (red.). 2014. Bourdieu and the Sociology of Translation and Interpreting, London: Routledge.

Kay France A. 1987. Boris Pasternak’s Translations of Shakespeare, Berkeley: University of California Press.

Khotimsky M. 2018. 'The Tenth Muse': Reconceptualizing Poetry Translation in the Soviet Era, w: B.J. Baer, S. Witt (red.), Translation in Russian Contexts: Culture, Politics, Identity, London: Routledge.

Kopper J.M. 1994. Dante in Russian Symbolist Discourse, „Comparative Literature Studies" 31(1), s. 25-51.

Lazzarin F. 2011. Samizdat e traduzione letteraria a Leningrado. Il caso di Predlog (1984-1989), ,eSamizdat” 8, s. 209-218.

Loseff L. 1984. On the Beneficence of Censorship. Aesopian Language in Modern Russian Literature, przeł. J. Bobko, München: Verlag Otto Sagner in Kommission. 
Lygo E. 2010. Leningrad Poetry 1953-1975: The Thaw Generation, Bern: Peter Lang. Maier C. 2002. Translation, Dépaysement and Their Figurations, w: M. Tymoczko, E. Gentzler (red.), Translation and Power, Amherst-Boston: Massachusetts University Press.

Milton J., Bandia P. (red.). 2009. Agents of Translation, Amsterdam: John Benjamin Publishing Company, s. 1-18.

Monticelli D. 2016. Reconfiguring the Sensible through Translation: Patterns of ,Deauthorisation”, „Translation and Interpreting Studies” 11(3), s. 416-435.

Parisi V. 2013. Il Lettore Eccedente, Bologna: Il Mulino.

Pavan S. (red.). 2009. Gli anni Sessanta a Leningrado, Firenze: Firenze University Press. Pomerantsev I. 2010. Brodsky on Donne: "The Poet Is Engaged In The Translation Of One Thing Into Another", Radio Free Europe Radio Liberty, 24.05.2010, https:// www.rferl.org/a/Brodsky_on_Donne_The_Poet_Is_Engaged_In_The_Translation Of_One_Thing_Into_Another/2051105.html (dostęp: 20.12.2020).

Presto J. 2008. Beyond the Flesh: Alexander Blok, Zinaida Gippius and the Symbolist Sumblimation of Sex, Madison: The University of Wisconsin Press.

Pym A. 2009. Humanizing Translation History, "Hermes" 42, s. 23-48.

Sabbatini M. 2008. "Quel che si metteva in rima": cultura e poesia underground a Leningrado, Salerno: Europa Orientalis.

Said E. 2000. Reflections on Exile and Other Essays, Cambridge: Harvard University Press.

Simeoni D. 1998. The Pivotal Status of the Translator's Habitus, „Target” 10(1), s. 1-39.

Tymoczko M. (red.). 2010. Translation, Resistance, Activism, Amherst - Boston: Massachusetts University Press.

Von Ziztewitz J. 2015. Religious Verse in Leningrad Samizdat: Origins and Confluences, „Enthymema” 12, s. 62-80.

Witt S. 2011. Between the Lines: Totalitarianism and Translation in the USSR, w: B.J. Baer (red.), Contexts, Subtexts, Pretexts, Amsterdam: John Benjamins Publishing Company.

Witt S. 2013. Arts of Accommodation: The First All-Union Conference of Translators, Moscow, 1936, and the Ideologization of Norms, w: L. Burnett, E. Lygo (red.), The Art of Accommodation: Literary Translation in Russia, Oxford, Bern, Berlin, Brux, Frankfurt am Main, NY, Wien: Peter Lang.

Wolf M., Fukari A. (red.). 2007. Constructing a Sociology of Translation, Amsterdam: John Benjamin Publishing Company.

Yeats W.B. 1994. The Collected Poems of W. B. Yeats, Ware: Wordsworth Editions Limited.

-1987. Poezje wybrane. Wybór, przekład i słowo wstępne L. Marjańska, s. 130-133.

Yurchak A. 2005. Everything Was Forever, Until It Was No More: The Last Soviet Generation, Princeton: Princeton University Press.

Zalambani M. 2009. Politica, censura e istituzioni in URSS (1964-1985), Firenze: Università degli Studi di Firenze. 